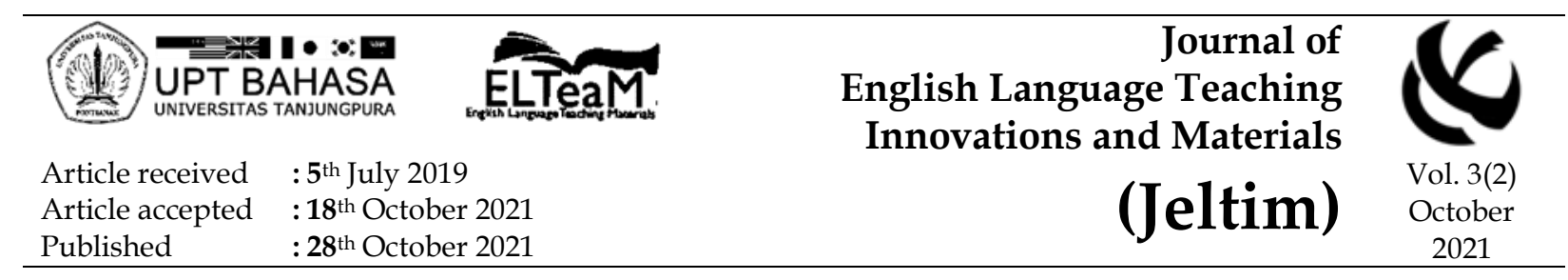

\title{
The effectiveness of spelling bee game through students' vocabulary mastery
}

\author{
Nyoman Karina Wedhanti ${ }^{1}$, Ni Made Ratminingsih ${ }^{2}$, Kadek Samiyanti ${ }^{3}$ \\ ${ }^{1}$ English Language Education, Ganesha University of Education, Denpasar, Indonesia \\ karinawedhanti@yahoo.com \\ 2 English Language Education, Ganesha University of Education, Denpasar, Indonesia \\ maderatminingsih@yahoo.com \\ ${ }^{3}$ English Language Education, Ganesha University of Education, Denpasar, Indonesia \\ kadeksamiyanti@gmail.com
}

\section{DOI: http://dx.doi.org/10.26418/jeltim.v3i2.33877}

\begin{abstract}
This study aimed at investigating whether or not there was a significant difference in vocabulary mastery between the students who were taught by using spelling bee game and those who were taught by using memorization through flash card. This research was quasi-experimental in nature. This study was conducted in pre-test and post-test design. The population was students of the fourth grade in elementary school in SD Negeri 3 Banjar Jawa. Random Sampling was assigned to determine the samples of the study. There were 30 students in Class A as the experimental group which was taught by using spelling bee game and 30 students in Class B as the control group which was taught by using memorization through flash card. The obtained data were analyzed through descriptive analysis and inferential analysis. The effect size was calculated by using Cohen's d testing. Based on the findings, the result proved that there was a significant difference in students' vocabulary mastery. The students who were taught using Spelling bee game also showed positive attitude during the learning process. There were three reasons why spelling bee game was better to be implemented, namely it helps the students to remember words better, it is enjoyable, and it makes students more active.
\end{abstract}

Keywords: vocabulary mastery; spelling bee game; memorization; flash card

How to cite this paper: Wedhanti, N. K., Ratminingsih, N. M., \& Samiyanti, K. (2021). The effectiveness of spelling bee game through students' vocabulary mastery. Journal of English Language Teaching Innovations and Materials (Jeltim), 3(2), 61-75. DOI: http://dx.doi.org/10.26418/jeltim.v3i2.33877

Journal of English Language Teaching Innovations and Materials (Jeltim), 3(2), 61-75

Copyright (C) 2021 by the authors, e-ISSN 2657-1617 
To link to this article: http:/ / dx.doi.org/10.26418/jeltim.v3i2.33877

This work is licensed under a Creative Commons Attribution

NonCommercial-ShareAlike 4.0 International License.

Vocabulary is one of the subject materials studied by all level students in Indonesia. It has to be mastered by students if they want to be fluent in English. Many experts already state their argument about vocabulary. According to Hornby (as cited in Alqantani, 2015), vocabulary is whole words that are required by someone to communicate ideas and to express meaning. Vocabulary is the core component of knowledge which is frequently functions as a basic instrument for second language learners. A learner with limited vocabulary in a second language will find it difficult to communicate (Schmitt, 2000). It means vocabulary is really needed in communication both orally and written form. Vocabulary is as a basic means when the speakers deliver message, they will use words which contain the meaning of the message. The more speaker master vocabulary the easier they communicate with interlocutor. It means that mastering vocabulary will help learners a lot to communicate well with the interlocutor. Thus, this is important for every learner to master the vocabulary as their foundation in language learning.

In learning a language, individual learners have their own style in acquiring foreign language especially in acquiring new vocabularies. It happens for adult learners and young learners. Lightbown and Spada (as cited in Caruth, 2013) stated that adult learners are students aged up to about 12. They are more discipline and have self-motivation in learning foreign language. They can learn foreign language through technology and visual presentation. Meanwhile young learners are students aged from just few years old up to about 12. Young learners need any help from any knowledgeable people to expand their knowledge (Pinter, 2006). Since they don't have enough knowledge or experience in order to follow the lesson. Besides, the young learners also learn from concrete environment. It helps them to master the lesson easier, for example using spelling bee, games, pictures, and story line. Because of the differences of learning style in learning foreign language, it is needed to use technique to support learning process in acquiring the language especially English.

Based on the pre-observation in the Fourth grade of SD Negeri 3 Banjar Jawa, the researcher found that most students still have difficulties in learning the vocabulary. The possible causes of the problems are the teaching techniques used by the teacher are still in a conventional way. The teacher only used question and answer technique and translation technique in teaching English. The teacher usually uses Indonesian and rarely uses English during the learning process.

Journal of English Language Teaching Innovations and Materials (Jeltim), 3(2), 61-75

Copyright (C) 2021 by the authors, e-ISSN 2657-1617 
Then, the students also do not have an English book. It makes the student only listen to the explanation of the teacher. Those problems decrease the interest and the motivation of the students to learn English.

Based on the problems above, the teacher should find the best or the effective technique to teach English vocabulary toward the students. Concerning to the characteristics of the young learners that they can easily get bored, need physical movements and real activities to stimulate their thought, and respond the language with the concrete to abstract meaning, then the teacher needs to find an appropriate teaching technique increase the eagerness of the students to learn English (Slatery\& Willis, 2001). So, it is important to create the class situation which can stimulate the students to learn. Spelling bee game is one of the teaching techniques which can be used to help the students to understand the English vocabulary easily (Rohmawati, 2015).

Spelling bee game is a competition where the participants have to spell every word given correctly. If the participant misspelled the word, then they are not able to continue the competition. According to Macmillan (2012), spelling bee game is an educational way used by the teacher to help the students to overcome the difficulties in spelling the word to be learned in the classroom. Moreover, O'Sullivan and Thomas (2007) stated that spelling bee game is a technique used by the teacher to teach English spelling system by implementing a variety of learning style in the classroom to improve students' understanding the spelling in English. Spelling bee game is not only used to remember the words but they also learn about the meaning of the words, antonym, synonym and also the pronunciation.

Considering that spelling bee game has gotten success in some teaching activities, it means it is appropriate for students in Elementary school. A study conducted by Maria, Pipit and Andri (2017) shows that the use of spelling bee game improves the students' vocabulary mastery. They further state that the mean score of the student improved. So, the use of this game will help students to understand the vocabulary well. Other study conducted by Ariningsih (2017) about the effectiveness of Spelling Bee Games in teaching vocabulary at the seventh-grade students of MTs Al-Hidayah Nusawungu. The result shows that the use of spelling bee game in teaching and learning process is more interesting. The study conducted by Sari (2017) further shows that the implementation of Spelling Bee Game can improve the students' vocabulary mastery and help the students to remember and memorize the vocabularies easily and carefully.

Based on the background of the study stated before, the problem of the study can be stated as "Is there any significant Effectiveness of Spelling Bee Game Through students' Vocabulary mastery at 4th Grade Students' of SD Negeri 3 Banjar Jawa in the Academic Year of 2018/2019?" 


\section{METHOD}

Quasi-experimental study was used in this research. This research done in order to know the difference of students's vocabulary mastery between students who were taught by using spelling bee and memorization through flash card. The researcher used Pre-test and Post-test Design. Pre-test was done before the treatment given and Post-test was given at the end of the treatment period or after the treatment was given. The population was fourth grade students of SD Negeri 3 Banjar Jawa, Singaraja district, Buleleng regency in academic year 2018/2019. The fourth-grade students consisted of 91 students, there are IV A, IV $B$ and IV C. In this study, the researcher used random sampling technique. From the process of random sampling, two groups were determined to become the sample of study. These classes were class IV A and class IV B students. Students in IV A class became experimental group and students in IV B class became the control group. In this study, the researcher used three instruments in collecting the data, namely lesson plan, pre-test and post-test.

The researcher followed these procedures of data collection; this was done in order to reach the purpose of this study, namely: First, preparing the instrument needed and consulted them to the researcher's supervisor. Second, asking permission from the headmaster of the school to conduct a researcher. Third, conducting cluster random sampling to choose two groups as the sample of the study. Fourth, asking students' English score to the teacher which will be tested through normality and homogeneity. Fifth, conducting normality and homogeneity test to know whether the score of both classes were in normal distribution or not. And then, determining the experimental group and the control group. The experimental group is taught using spelling bee and the control group is taught using conventional technique. Finally, administering the treatments; experimental and control group are taught by using different treatment.

The data were analyzed using descriptive statistics analysis and inferential statistics analysis. Descriptive statistics analyze the data collection by calculating the mean, median, mode, range, variance, and standard deviation. This inferential statistic was used to see whether the independent variable gage significant effect on the dependent variable. Normality test and homogeneity test was conduct before t-test as the prerequisite test of hypothesis testing. It was intended to know whether the data was in normal distribution and homogeneous or not.

Journal of English Language Teaching Innovations and Materials (Jeltim), 3(2), 61-75

Copyright (C) 2021 by the authors, e-ISSN 2657-1617 


\section{FINDINGS}

\section{Data Transcription}

In this study, the data description provided the information about the central tendency of the data which included mean, median, mode, range, variance, and standard deviation of the data both from the experimental group and the control group.

Table 1. Descriptive Data

\begin{tabular}{ccc}
\hline Statistic & Experiment Group & Control Group \\
\hline Mean & 82.13 & 45.80 \\
\hline Median & 83 & 44 \\
\hline Mode & 83 & 39 \\
\hline Deviation Standard & 8.24 & 8.49 \\
\hline Variance & 67.91 & 72.16 \\
\hline Range & 30 & 31 \\
\hline Minimum Score & 67 & 33 \\
\hline Maximum Score & 97 & 64 \\
\hline
\end{tabular}

Table 1 shows that the mean score of experimental group was higher than the mean score of students in the control group. The mean score of students who were taught by using Spelling Bee Game was 82.13. Meanwhile, the mean score of students who were taught by using memorization through was 45.80 . Through the descriptive statistical analysis it can be inferred that the students who were taught by using Spelling Bee Game performed better than the students who were taught by using flashcard media.

From the data obtained through post-test, the distributions of data in each group were presented in the form of table and histogram. The data distribution of each group is presented in the following explanation.

\section{Vocabulary Mastery of Students in Experimental group}

The frequency of score distribution can be seen on the following table.

Table 2. Frequency of Score Distribution of the Experimental Group

\begin{tabular}{cccc}
\hline Frequency score & Midpoint & Frequency & Percentage \\
\hline $67-69$ & 68 & 3 & $10 \%$ \\
\hline $72-75$ & 73 & 4 & $13 \%$ \\
\hline $78-81$ & 79.5 & 6 & $20 \%$ \\
\hline $83-86$ & 84.5 & 7 & $23 \%$ \\
\hline $89-92$ & 90.5 & 8 & $27 \%$ \\
\hline $94-97$ & 95.5 & 2 & $7 \%$ \\
\hline & & 30 & $100 \%$ \\
\hline
\end{tabular}


Based on the data presented in Table 2, it can be seen that the lowest score in experimental group was in the first interval, there were 3 students or $10 \%$ of students got score in the interval 67-69. There were 2 students or $7 \%$ of students got the highest score interval that is 94-97. The distribution of the data based on the midpoint of each interval can be seen on the following histogram.

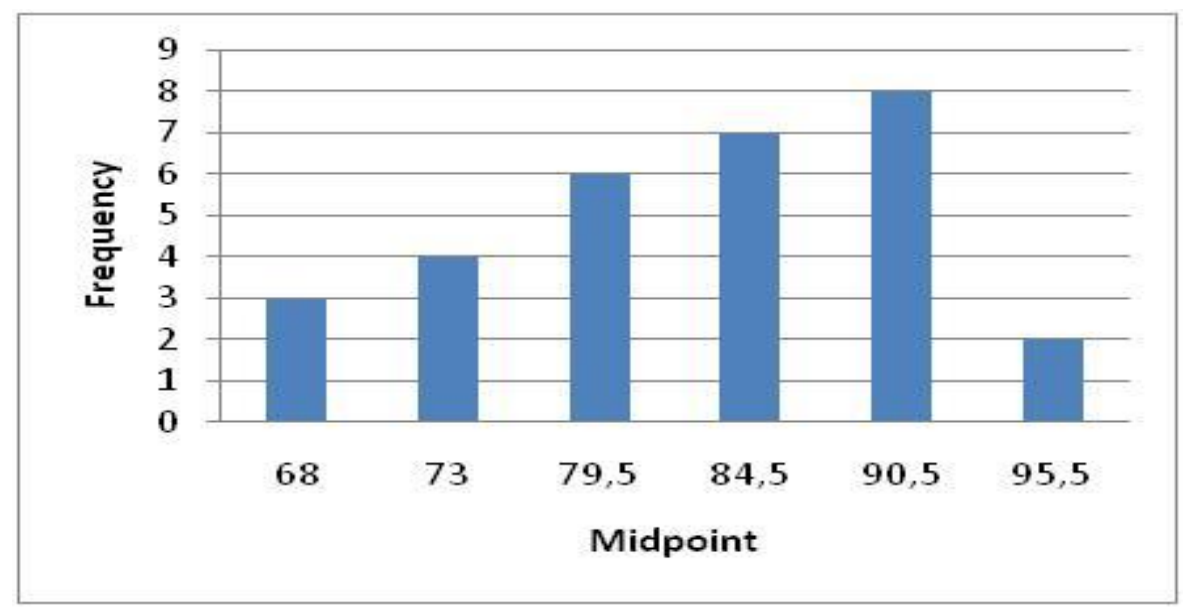

Figure 1. Midpoint Distribution of the Experimental Group

From the histogram above, it can be seen the highest and the lowest midpoint of the data set. The highest frequency was in the fifth midpoint that was 90.5. Meanwhile, the lowest frequency was in the sixth midpoint that was 95.5

\section{Vocabulary Mastery of Students in Control Group}

The frequency of the score distribution can be seen on the following table.

Table 3. Frequency Score Distribution of the Control Group

\begin{tabular}{cccc}
\hline Frequency score & Midpoint & Frequency & Percentage \\
\hline $33-36$ & 34.5 & 4 & $13 \%$ \\
\hline $39-42$ & 40.5 & 8 & $27 \%$ \\
\hline $44-47$ & 45.5 & 7 & $23 \%$ \\
\hline $50-53$ & 51.5 & 5 & $17 \%$ \\
\hline $56-58$ & 57 & 4 & $13 \%$ \\
\hline $61-64$ & 62.5 & 2 & $7 \%$ \\
\hline & & 30 & $100 \%$ \\
\hline & Total & &
\end{tabular}

Based on the data presented on the Table 3, it can be seen that the lowest scores were in the first interval. There were $13 \%$ of students got score in the interval of $33-36$. There were only 2 or $7 \%$ of students got the highest score in the 
interval score 61-64 The distribution of the data based on the midpoint of each interval can be seen on the following histogram

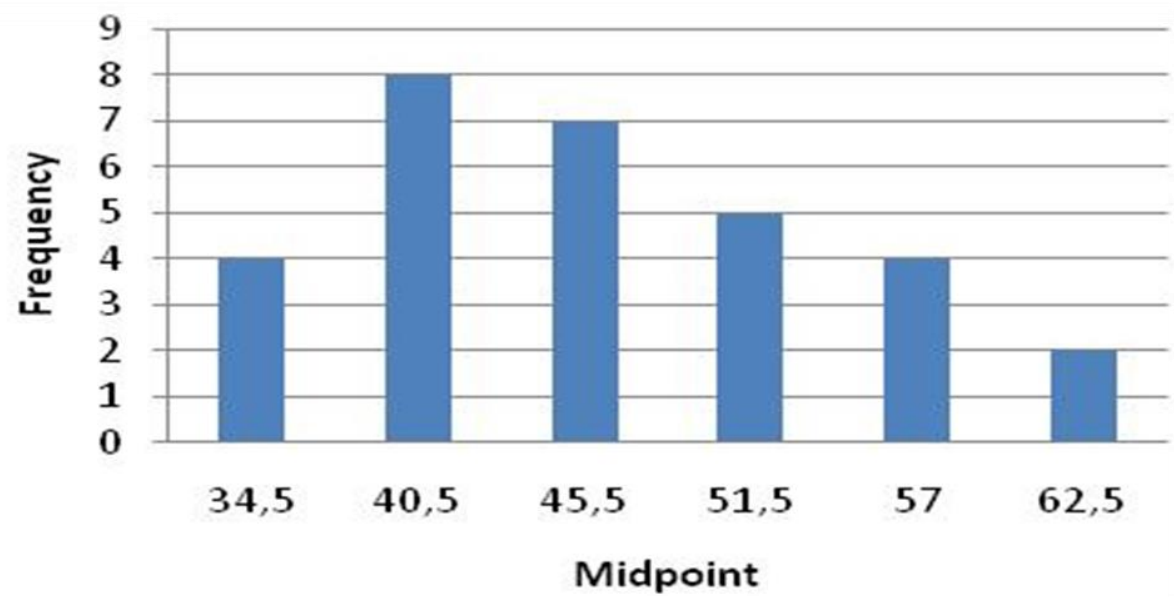

Figure 2. Midpoint Distribution of the Control Group

The histogram above shows that the highest frequency was in the second midpoint that was 40.5. Meanwhile the lowest frequency was in the sixth midpoints that was 62.5 .

\section{Requirement Tests for Hypothesis Testing}

The requirement tests were normality test and homogeneity of variance test. The analysis of each requirement tests of data was presented in the following section.

\section{Normality Test}

Normality test was used to determine if the data were in normal distribution or not. The result of normality test of both groups can be seen in the following table.

Table 4. The Result of Normality Test

Tests of Normality

\begin{tabular}{|l|r|r|r|r|r|r|}
\hline \multirow{2}{*}{} & \multicolumn{3}{|c|}{ Kolmogorow-Smimor } & \multicolumn{3}{|c|}{ Shapiro-Willk } \\
\cline { 2 - 7 } & Statistic & \multicolumn{1}{c|}{$\mathrm{df}$} & \multicolumn{1}{c|}{ Sig. } & \multicolumn{1}{c|}{ Statistic } & \multicolumn{1}{c|}{$\mathrm{df}$} & \multicolumn{1}{c|}{ Sig. } \\
\hline Experiment & .131 & 30 & .200 & .960 & 30 & .304 \\
Control & .151 & 30 & .081 & .955 & 30 & .224 \\
\hline
\end{tabular}

a. Lilliefors Significance Correction

${ }^{*}$. This is a lower bound of the true significance. 
Based on the table 4, the significant value of the data in Shapiro-Wilk column was 0.304 for the experimental group and 0.224 for the control group. The significant value of the two groups exceeded the value of alpha that is 0.05 . Thus, the result indicated that the data gained from the two groups had normal distribution.

\section{Test of Homogeneity of Variance}

Test of homogeneity of variance was conducted in order to know whether the groups of the study were homogeneous or not. The result of homogeneity test of scores gained by the two groups can be seen on the following table.

Table 5. The Result of Homogeneity Test

\begin{tabular}{|c|c|c|c|c|c|}
\hline & & $\begin{array}{l}\text { Levene } \\
\text { Statistic }\end{array}$ & df1 & $\mathrm{df2}$ & Sig. \\
\hline \multirow[t]{4}{*}{ Experiment } & Based on Mean & .107 & 1 & 58 & .745 \\
\hline & Based on Median & .041 & 1 & 58 & .841 \\
\hline & $\begin{array}{l}\text { Based on Median and } \\
\text { with adjusted df }\end{array}$ & .041 & 1 & 57.790 & .841 \\
\hline & Based on trimmed mean & .093 & 1 & 58 & .762 \\
\hline
\end{tabular}

Based on the result showed in Table 5, it can be seen that the significant value of the data was 0.745 . The significant value was higher than the alpha that is 0.05. In other words, the data obtained from the two groups were homogeneous. From these results, the data can be categorized as homogeneous in terms of variance. It means that the independent t-test can be conducted to make the generalization whether or not Spelling Bee Game gives significant difference towards students' vocabulary mastery at fourth grade students in SD Negeri 3 Banjar Jawa in academic year 2018/2019.

\subsection{Hypothesis Testing}

The alternative hypothesis proposed in this research was "is there a significant difference of using Spelling Bee Game towards students' vocabulary mastery" If the significance (two tailed) calculated is smaller than 0.05 , then $\mathrm{H}_{\mathrm{a}}$ is accepted. The result of test can be seen in Table 6 . 
Table 6. The Result of Pre-test of Students' Vocabulary Mastery

Independent Sample Test

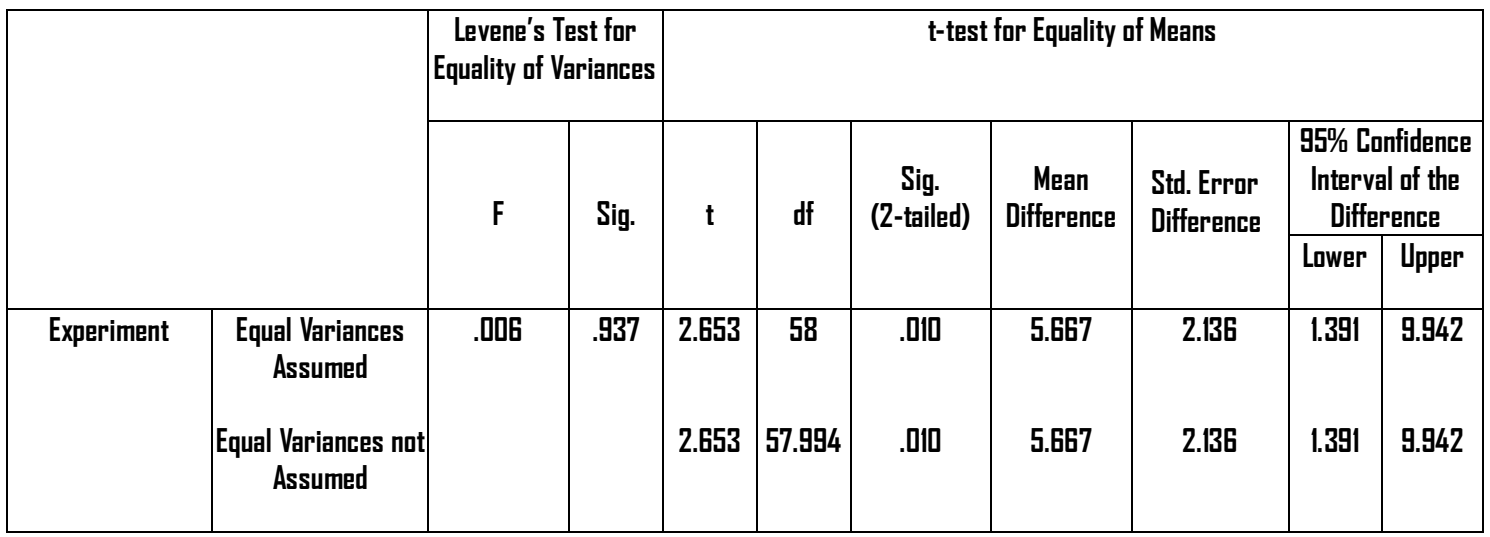

Based on Table 6, sig. (2-tailed) is 0.010 which is under the significant value or alpha level $0.05(0.010<0.05)$. So, the null hypothesis $\left(\mathrm{H}_{0}\right)$ is rejected and the alternative hypothesis $\left(\mathrm{H}_{\mathrm{a}}\right)$ is accepted. It means that there is significant difference of students taught by using Spelling Bee Game and the students taught by using memorization through flash card.

Table 7. The Result of Post-test of Students' Vocabulary Mastery

Independent Sample Test

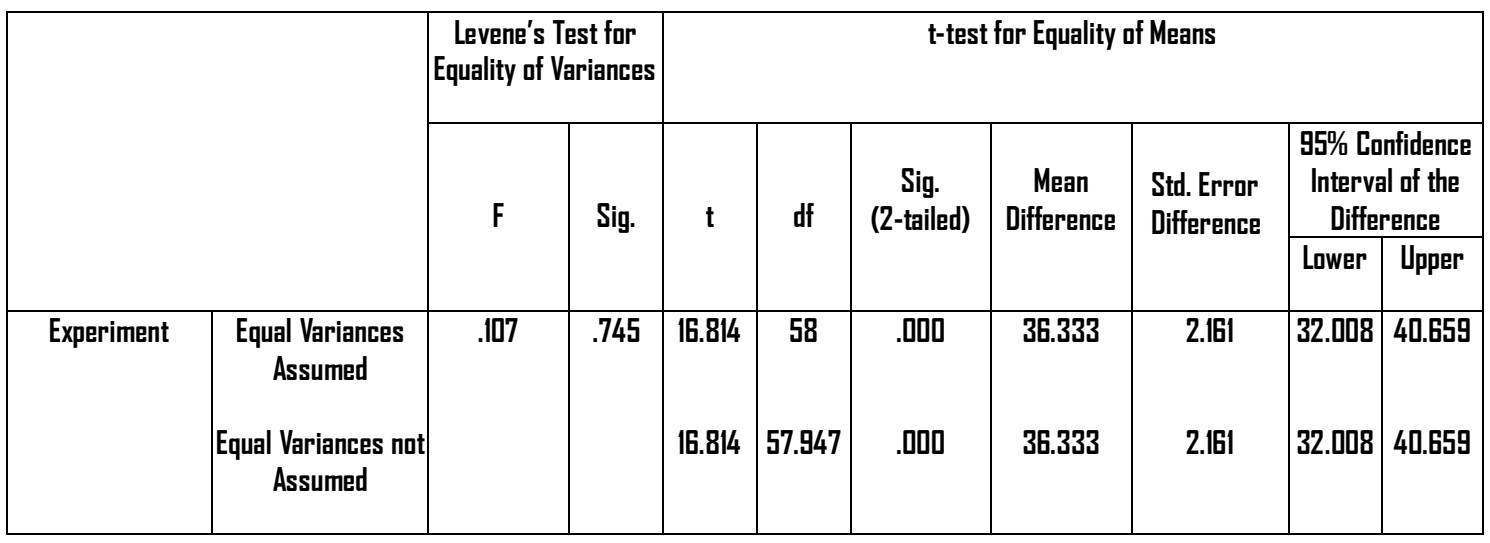

Table 7 shows the information of t-test result of the students' vocabulary mastery. The alpha level is 0.05. Based on the table above, it shows the significant value of both groups (0.000) is smaller than the alpha level $(a=0.05)$. It can be assumed that there is a significant difference between both scores. Furthermore, the hypothesis testing also has been analyzed in terms of the $t$ observed $\left(t_{o b s}\right)$ and $t$ critical value $\left(t_{c v}\right)$. The comparison between $t_{o b s}$ and $t_{c v}$ was done to measure whether or not the mean scores of two groups were significantly different. It was tested by using critical value of the t-distribution. Based on the table 4.7 above, 
the $t_{\text {obs }}$ is 16.814 at the degree of freedom (df) 58. The $t_{c v}$ of 58 is 2.021. In brief, $t_{o b s}$ is higher than $t_{\mathrm{cv}}(16.814>2.021)$, which means that the null hypothesis is rejected.

\subsection{Effect Size}

In this study, the researcher also conducted the effect size calculation. The effect size of this study is 2.06. Based on Cohen's d statistic for effect size, it is categorized as high effect size. The clear calculation can be seen below.

$$
\begin{aligned}
& d=\frac{M_{\text {group } 1}-M_{\text {group 2 }}}{S D_{\text {pooled }}} \\
& d=\frac{M_{\text {group } 1}-M_{\text {group 2 }}}{\sqrt{\left(\mathrm{SD}_{\text {group } 1}^{2}+\mathrm{SD}^{2} \text { group 2 }\right) / 2}} \\
& d=\frac{M_{\text {group } 1}-M_{\text {group } 2}}{S D_{\text {pooled }}} \\
& d=\frac{0.46-0.14}{\sqrt{0.20+0.08) / 2}} \\
& d=0.85
\end{aligned}
$$

Based on the effect size calculation above, the effect size of Spelling Bee Game is 0.85. It means that the effect size of the technique is categorized into high effect size and it is concluded that there is a significant effect using Spelling Bee Game on student's students' vocabulary mastery in the fouth grade students of SD Negeri 3 Banjar Jawa in academic year 2018/2019.

Table 8.Criteria of Cohen d Statistic

\begin{tabular}{ll}
\hline Score & Effect Size interpretation \\
\hline 0.20 & Low Effect Size \\
\hline 0.50 & Medium Effect Size \\
\hline 0.80 & High Effect Size \\
\hline
\end{tabular}

To sum up, based on the result of descriptive analysis, inferential statistics analysis, and effect size, it can be concluded that there is a significant effect of using Spelling Bee Game through fourth grade students' vocabulary mastery of SD Negeri 3 Banjar Jawa in academic year 2018/2019.

\section{DISCUSSION}

After post-test was given to both groups, then the data were compared to each other. To see the differences between mean score of using 
Spelling Bee Game and memorization through flash card effect in students' vocabulary mastery, SPSS 16.0 was used in analyzing and comparing the obtained data. The result shows that experimental group achieved higher score of vocabulary mastery than control group. It indicated that students in experimental group were obviously doing better in their test. It means that there is significant effect of using Spelling Bee Game as the authentic learning technique toward students' vocabulary mastery on fourth grade students of SD Negeri 3 Banjar Jawa in academic year 2018/2019. It means that the students who were taught by using Spelling Bee Game were achieve better result than using memorization through flash card.

Actually, this finding has been reflected on the learning process which was observed by the researcher. The Students who were taught by Spelling Bee Game has showed different attitude toward teaching and learning process rather than students who were taught by using memorization through flash card. At least there were three reasons observed through the teaching learning process which indicated why Spelling Bee Game can give better result on students' vocabulary mastery.

First of all, obviously Spelling Bee game helps the students to remember the vocabularies better. Choosing an appropriate learning strategy can help the students to involve more in the teaching and learning process especially for young learners. Suyanto (2007) stated that some of students can learn very fast and some students need more time to learn. Teachers should be aware of all the differences that are owned by students, so the teachers can choose the right activities to be used in the teaching and learning process. One of interesting ways to engage the student in the learning process is through game. Kim (1995:35) states that there are many advantages of using game in the classroom. One of those advantages is games help students to make and sustain the effort of learning. The students will deeply involve in the teaching and learning process; they will memorize the material better. For example, on the second meeting when the teacher asked about previous material, most of the students could answer the teacher's questions. The students remembered the vocabularies in the previous meeting. This phenomenon is in line with the study conducted by Sari (2017). She stated that Spelling Bee Game helps the students in remembering and memorizing the vocabularies easily and carefully and improves students' accuracy in pronouncing words and increase their motivation in learning English. In addition, Yusuf, Mustafa, and Alqinda (2017) stated that Spelling Bee game makes the students remember and easier to understand the meaning of the words.

On the other hand, students in control group were just observing and memorizing the picture with words (vocabulary) or without words. Teacher, off course, gives some instructions to the students. Additionally, flash card which 
contains picture is good for getting students attention. Slattery and Willis (2001) stated that young learners prefer to listen, watch and doing something which they like. However, teaching using flash cards only tends to be boring for the students. The use of flash card tended to make students just learn in more visual manner. They remember based on what they see which makes the result of their test is lower than experimental group.Additionally, students have different learning style, some of them could understand by visual manner but most of students especially young learners would understand well if they are taught using innovative strategy or technique. Seeing the picture in once will not make the students understand or remember better.

The second reason is learning through Spelling Bee Game is more enjoyable than learning by using memorization through flash card, this finding is correlated with the study conducted by Nikita (2016) which found out that the students' enthusiasm improved from $56 \%$ to $80 \%$. In her study, she conducted a study using Spelling Bee Game in two cycles. In the first cycle, $56 \%$ of the students more enthusiasm rather than in the second cycle showed that the students' enthusiasm increased to $80 \%$. Furthermore, a study conducted by Ariningsih (2017) showed that the use of Spelling Bee Game in teaching and learning process is more interesting. Baudains and Baudains (1990) argue that learners should always find immediate enjoyment in their class work. This is the basis why teachers should use game. In many cases, young learners are loved to play game. They understand games as a natural part of their lives. Furthermore, Thornbury (2004) affirmed that to make learning vocabulary work very well it would be wrong to suggest that vocabulary learning has to be all work and no play.

Students in experimental group were obviously enjoying the teaching learning process itself. On the other hand, the students in control group only could learn by memorizing the picture in flash card. The pictures might be interesting, but with no upcoming activity the classroom atmosphere will be boring. Young learners have short attention span; therefore teacher should choose an appropriate way to engage the young learners to be enthusiastic in teaching and learning process. When the young learners were less enthusiastic, they will have lack of interest. Since they lacked of interest, the researcher observed the students in control group that they became easy to forget new vocabulary. For example, when the students already learnt about family members, and then in the next meeting teacher tried to review previous material, the students seems difficult to memorize the vocabularies in the flash card. However students in control group just sitting in their chair and looking into pictures in flash card.

The third reason is Spelling Bee Game drives the students to be more active during the learning process. There are many advantages of using game in the classroom, one of them is game are challenging and motivating. Games also create a competitive atmosphere. In competitive atmosphere, the students 
unconsciously involve in the learning; they are trying to show that they want to be the best. For example, in experimental group, when the teacher implemented the Spelling Bee Game, the students were divided into several groups and when the game started the students in each group tried to answer the teacher's question as quick and much as they could. They tried to collect as much score as they could to show that they were the best team among all of them. Through that activity, the students were unconsciously active during the learning process. This phenomenon is in line with the study conducted by Ningsih (2013). She stated that the implementation of Spelling Bee Game is recommended for teacher to build amusing atmosphere for students in learning vocabularies. She further stated that through amusing atmosphere, the students become involved in the learning process. Additionally, Rohmawati (2015) also stated that Spelling Bee Game encourages students' motivation in learning vocabulary. Further, she stated that students become more active in answering the question and telling the definition of the words. Students also got themselves to be more confident, so they learn without feeling any burden.

On the other hand, the students in control group seem to be more reluctant to be involved during learning process. Teaching using memorization through flash card only creates less interesting atmosphere. Some students are attracted by the flash cards, but most of them are not. When the teacher gives questions to the students, only some of them answer the question. The rest of them remain silent and have less interest to answer the question.

\section{CONCLUSION}

From the analysis displayed previously, it can be concluded that there is a significant effect of using Spelling Bee Game toward students' vocabulary mastery at fourth grade students in SD Negeri 3 Banjar Jawa on academic year 2018/2019.

To sum up,spelling bee game is effective to teach vocabulary. However, it does not mean that memorization through flash cardsdoes not work well for students' vocabulary mastery. This finding shows that the use of Spelling bee game is proven to be better in its implementation.

\section{SUGGESTION}

From the result of the study above, there are several suggestions given. All suggestions were listed below.

1. It is already proven that Spelling Bee Game has a significant effect on students' vocabulary mastery. Therefore, it is recommended for English teacher to use Spelling Bee Game because students' vocabulary mastery is positively affected. 
2. This research is far from perfection because of its limitation on population, sample or variables involved. Therefore, further research may focus on other samples or dependent variable. Therefore, it is encouraged to conduct other research which will explore the benefit of this technique further.

\section{REFERENCE}

Alqahtani, M. (2015). The Importance of Vocabulary In Language Learning and How to be Taught, 3(3): 21-34

Arikunto, S. (2010). Prosedur Penelitian Suatu Pendekatan Praktik. Jakarta: Rineka Cipta.

Baudains, R. \& Baudains, M. (1990). "Alternatives: games, exercises and conversations for the language classroom". London: Longman.

Caruth, G. (2013). Toward an Understanding of Andragogy's Role in the Online Curriculum of the Higher Education System. International Women Online of Distcance Education, 2(2): 37-44.

Juhana. (2014). Teaching English to Young Learners: Some Points to be Considered. "Asian Journal of Education and e-Learning", 2(1): 43-46

Macmillan. 2012. ABC Brainwave Spelling Bee Handbook. New Jersey: Macmillan Publisher. Ltd

Nikita (2016). "The Use of Spelling Bee Game to Improve Students' Understanding of Simple Past Tense". Retrieved from http://eprints.walisongo.ac.id/6076/1/113411055.pdf

Ningsih, R. J. (2013). The use of spelling bee game to improve students' vocabulary mastery "Unpublished Bachelor's thesis". Universitas Pendidikan Indonesia. Bandung

O'Sullivan, O., \& Thomas, A. (2007). “Understanding Spelling”. London: Routledge.

Pinter, A. (2006). “Teaching Young Language Learners". Oxford: University Press.

Rohmawati, A. (2015). Speeling Bee in Teaching Vocabulary. Journal of English and Education, 3(2):1-15.

Sari, Y. (2017). The effect of spelling bee game on students' vocabulary mastery. "Unpublished Bachelor's thesis". UIN Ar-Raniry. Banda Aceh. 
Schmitt, N. (2000). “Vocabulary in Language Teaching”. Cambridge: Cambridge University Press.

Slattery, M., \& Willis, J. (2001). “English for Primary Teachers". Oxford University Press: Oxford.

Suyanto, K. K. E. (2007). “English for Young Learners”. Jakarta: Bumi Aksara.

Thornbury, S. (2002). How to teach vocabulary. Longman Essex.

Yusuf, Y. Q., Mustafa, F., and Alqinda, M. (2017). The Use of Spelling Bee Game in Teaching Vocabulary to Junior High School Students. "Proceedings of The 1st National Conference on Teachers' Professional Development", 242-249.

\section{Authors' Brief CV}

Nyoman Karina Wedhanti is a lecturer at the Undergraduate and the Masters' of English Language Education study programs of Universitas Pendidikan Ganesha (Undiksa), Singaraja, Bali, Indonesia.

Ni Made Ratminingsih is a Professor of English Language Teaching at the Undergraduate and the Masters' of English Language Education study programs of Universitas Pendidikan Ganesha (Undiksa), Singaraja, Bali, Indonesia.

Kadek Samiyanti is a student of the English Language Education study program of Universitas Pendidikan Ganesha (Undiksa), Singaraja, Bali, Indonesia. 